\title{
Educational Management of Innovative Pedagogical Process in Higher Education Institutions (HEIs)
}

\author{
Olena I. Kravchenko ${ }^{1}$, Dmytro S. Tymchuk ${ }^{2}$, Tetiana H. Pavlysh ${ }^{3}$, Dmytro P. Kyslenko ${ }^{4} \&$ Olena V. Lutsenko 5 \\ ${ }^{1}$ Department of Public Service and Management of Educational and Social Institutions, Educational and Research \\ Institute of Public management, Administration and Postgraduate education, Luhansk Taras Shevchenko National \\ University, Starobilsk, Ukraine \\ ${ }^{2}$ Department of Social-Humanitarian and Biomedical Sciences, Kharkiv Institute of Medicine and Biomedical \\ Sciences of Kyiv Medical University, Kharkiv, Ukraine \\ ${ }^{3}$ Department of Special Engineering and Information Technology, Donetsk Law Institute of the Ministry of Internal \\ Affairs of Ukraine, Kryvyi Rih, Ukraine \\ ${ }^{4}$ National University of Ukraine on Physical Education and Sport, Kyiv, Ukraine \\ ${ }^{5}$ Department of Foreign Languages for Natural Sciences Faculties, Institute of Philology, Taras Shevchenko National \\ University of Kyiv, Kyiv, Ukraine \\ Correspondence: Olena I. Kravchenko, Luhansk Taras Shevchenko National University, 1 Gogol Square, Starobilsk, \\ 92703, Ukraine.
}

Received: June 10, 2020

Accepted: August 3, 2020

Online Published: August 4, 2020

doi:10.5430/ijhe.v9n7p1

URL: https://doi.org/10.5430/ijhe.v9n7p1

\begin{abstract}
The article proves that one of the objectives of the contemporary high school is developing the potential of all participants of the pedagogical process, giving them opportunities for revealing creative abilities. Such a change in the role of education in society has led to innovative processes. We distinguish the following elements of innovative activity in HEIs: the goal (increasing the efficiency of resource use in the HEIs), the content (the processes of creating and applying the innovations, including regular ones) and the product (the quality of training the graduates of the HEIs). We also identified the following types of innovation: organizational, processive and productive, which are the subjects of innovative activity in the HEIs. Under these circumstances, the planning and application of innovations are considered as the area of involving teachers into innovation activity. We specified the factors increasing the number of innovative activities: organizational and technological preparation of creating innovations is considered pre-innovation activity; the production of innovations depends on research and scientific work; the application of innovations includes the stages of implementation, design and dissemination. We distinguished contextual, educational, scientific and innovative processes and the process of strategic development of human potential. We identified the prospects of researching the innovative environment of HEIs as a condition for effective innovative activity of teachers. Generally, the structure of indirect management of the innovative process includes the main stages of the reflexive regulation of searching a new idea: the stages of criticism, conscious rethinking and normalization of the activity. The organizational structure of such management includes the following stages: diagnostic, regulatory, analytical and verification. Knowledge of the varieties of structures and their main stages is necessary to define the whole system of reflective management, because the innovation process consists of micro-innovation processes, which need to be adjusted in communication. We analysed the basic structural components of the authors' technology of managing the innovation process at the department level as a structural part of HEIs.
\end{abstract}

Keywords: innovative process, innovations, higher education institution, teachers, management, quality, educational process, innovative educational process, department

\section{Introduction}

The accelerated development and global integration of social production and the informatization of society require appropriate changes in education (Kneale et al., 2016). Considering the fact that the requirements for the level and quality of education are changing in line with changes in social and economic life, the nature of the educational 
process in a higher education institution (hereinafter referred to as HEI) should be innovative.

At present, significant changes in the national education policy are taking place in our country. This is due to the transition to a position of self-oriented pedagogy. One of the tasks of the modern high school is to reveal the potential of all participants in the pedagogical process, to give them the opportunity to show creative abilities. Such a change in the role of education in society has mostly led to of innovative processes. Regarding innovation in higher education, the researchers distinguish three levels of innovation: conceptual, organizational, activity, scientific and methodological.

1. The conceptual level reflects the need to perform the following tasks:

- Methodological substantiation of prior general scientific ideas necessary and sufficient for the development of the concept of restoration;

- Orientation to such a pedagogical theory that would give an idea of the integrity of the educational process;

- Reflection of the specific work of a definite HEI in the concept.

2. The organizational and activity level implies the achievement of the following goals:

- Selection and appointment of pedagogical staff within HEI, search and involvement of scientific consultants, specialists for conducting new courses and electives;

- Creation of a scientific and methodological council for planning, coordination and control of experimental work;

- Organization of creative teams of experimental teachers for development and pilot testing of new courses;

- Provision of logistical conditions for conducting experimental work.

3. The scientific and methodological level provides for:

- Development and testing of different variants of curricula, programs, ways and means of their achievement;

- Development of methods of diagnosing the level of education and obtaining of knowledge;

- Distinguishing the effectiveness criteria for implementing the concept of education of this HEI;

- Defining an effective mechanism for generalizing and disseminating best practices and innovations;

- Scientific support for effective ways of teacher training and qualification.

The above described levels cover the necessary areas for designing innovations within the framework of the HEI. These areas relate to the design part of the innovation, which needs to be complemented by implementing a list of conditions to accompany the realization of innovations (Watty, McKay \& Ngo, 2016).

Otherwise, the necessary conditions for the implementation of the innovation may not appear, and the project will remain unfulfilled. At the implementation level, it is necessary to describe the main activities of all participants of the innovation, determine the funds and conditions for realizing the plan, establish a mechanism for monitoring and adjusting the innovative process. The listed stages of innovative pedagogical activity presuppose the traditional approach of "putting science into practice". Taking into account the personally oriented education paradigm, it is necessary to plan the situations of involving the subjects of innovative education in the process of its implementation and, if necessary, the transformation.

To summarize, it should be noted that the formation of plans, preparation and gradual implementation of innovative changes is called the innovative process. The innovative process is a broader concept than innovation activity (Koehler, Mishra, Kereluik, Shin, \& Graham 2014). It can be viewed from different positions and in different degrees in detail:

- Firstly, it can be considered as a parallel and sequential implementation of research, scientific, technological, industrial activities and innovations;

- Secondly, viewed as temporary stages of the innovation life cycle from generating the idea to its development and implementation.

Alongside, it is necessary to emphasize that the organization and management of the innovative process in higher education require qualified managers and teachers. After all, nowadays, in the management of Higher Education Institutions, priority is given to the problems of improving the quality of education in accordance with the main directions of modernization, inclusion into the Bologna process, which identified the main tendencies in development of the "zone of European higher education" in the near future. The Berlin Communiqué, which was 
signed in May 2005 and led to the entrance of Ukraine to the Bologna Process, emphasizes that "the quality of higher education is in the core of building the European Higher Education Area" (Sadkovy \& Dombrovska, 2012).

In addition, the Ministers of Education commissioned the European Network of Quality Assurance in Higher Education (ENQA) in collaboration with other European organizations: EUA (European Universities Association), EURASHE (European Association of Higher Education Institutions), ESIB (European Student Information Bureau) to develop agreed standards, procedures and quality assurance techniques, and to find ways to guarantee the quality of education through external assessment systems.

Thus, the quality of higher education is determined, along with a number of other factors, by innovations in the pedagogical process. The general and specific features of innovative pedagogical activity were studied in the works of many scholars (Dysart \& Weckerle, 2015; Ridey, 2010; Tolochko, 2016). In foreign pedagogy, problems of innovation planning and management of innovation processes are also reflected in the scientific achievements of the authors studied (Stefani, 2013; Stes, De Maeyer, Gijbels \& Van Petegem, 2013; Stewart, 2014).

The problems of managing innovations in HEI are investigated in various fields of science, which defines the basic concepts: "innovative environment of HEI", "innovative activity in HEI". The author's definitions reflect the specificity of the sciences, taking into account the functioning of the HEI as an element of economic relations and as an educational organization (Bendahmane, El Falaki \& Benattou, 2019; Webster \& Whitworth, 2019).

In particular, Bondar (2013), using economic approaches to managing the innovative environment of a higher education organization, defines the innovative activity of the HEA as "a holistic set of processes of regular production and application of productive, process and organizational innovations that ensure the increase in efficiency of using all types of resources of the institution of higher professional education. While improving the quality of training specialists and optimizing their numbers in accordance with current and perspective needs of society".

Based on the position of the author, innovation can be considered as a set of processes of production and implementation of innovation. These are innovations that make it possible to effectively use the resources of the higher educational organization to improve the quality of graduate education. The same idea sounds in the work of Starostina, Kravchenko and Nazvanova (2013). According to the authors, innovations in educational, scientific and information activities "allow to develop innovative infrastructure, to replicate high-tech technologies on the market, to teach students on the basis of their involvement in scientific and innovative environment".

Appealing to these positions, we highlight the following elements of innovation activities in HEI: purpose (increase in resource efficiency in HEI), content (regular processes of creation and application of innovation) and product (the quality of training graduates of HEI). The types of innovation are also identified: organizational, process and productive, which are the subjects of innovation in the HEI. In such circumstances, we consider the design and implementation of innovations as the area of involving teachers into innovation.

Similar to Bondar's (2013) point of view, Gamayunov (2003) considers innovative activity in HEI as a set of processes. The author specifies its components: research and exploration scientific works, educational, scientific and innovative process, organizational and technological preparation for the creation, implementation and dissemination of innovations in other areas. And unlike other researchers, he singles out the strategic process of human capital formation.

Suprun and Novytska (2015) specified the factors, the presence of which increases the number of innovative processes: organizational and technological preparation for creating innovation is referred to as pre-innovation activities; the production of innovations is specified by research and development types of works; the application of innovation includes the stages of implementation, design and dissemination. Educational, research and innovation processes and the process of strategic formation of human potential can be distinguished as contextual ones. We believe that "university teachers can be involved in all systematic processes" (Ravhuhali, Kutame \& Mutshaeni, 2015).

Meanwhile, it should be noted that the quality of innovation is crucial for the functioning of the HEI. According to Sidorenko (2016), the quality of research and development work is determined by the innovative activity of scientific and pedagogical workers, which allows to maintain their knowledge, potential and practical experience at a high level. This, in turn, ensures higher quality training for the higher-skilled staff.

Moreover, innovation is a source of attracting additional financial resources, which contributes to the competitiveness of the HEI. Thus, the involvement of teachers of higher education institutions into innovation activities enhances the quality of educational services provided. The university management system must be able to 
manage not only the conceptual phase of the problem based on the results of basic and exploratory research, obtained patents, but also a complete innovation cycle: from the idea to the creation of the finished product, its replication and transfer to the market.

Increased attention not only to the economic or technical, but especially to the managerial and socio-organizational side of the innovative process is noted in scientific works in various fields of knowledge (Engelbrecht \& Ankiewicz, 2016; Gast, Schildkamp \& van der Veen, 2017). Defining the leading role of the organization's managers in their reaction to changes reflects the specifics of the sociological approach to the study of innovation.

The importance of highlighting innovation as a particular subject of educational management is emphasized by leading scholars (Aškerc \& Kočar, 2015; Bovill, Cook-Sather, Felten, Millard, \& Moore-Cherry, 2016; DCU, 2018). Management in the field of education is considered by the authors "as the art of managing material, intellectual, financial, human resources on the basis of the fullest realization of the physical and spiritual potential of a person in order to achieve the optimum socially significant result in accordance with current legal norms" (Shorobura, 2010). In a rapidly changing environment, a new management subsystem is emerging - an innovative subsystem of an educational institution that anticipates changes through the research, development and implementation of innovations in a specific part of the whole system (Prokopenko, 2013).

The concept of "innovation management in an educational institution" is emerging (Shorobura, 2010). Scientists define it as a purposeful activity of subjects of management of different level, aimed at meeting any educational need and achievement of more effective activity results providing continuous development of the whole managed system of educational institution by means of complex activity in creation, development of innovations in practical education and training, dissemination and exchange of pedagogical experience, management of all resources of an educational institution, development of new forms of interaction with society, their implementation spread to other areas (Ridey, 2010).

The conditions that affect the effectiveness of innovation in the HEI are determined. They include the innovation environment, more precisely, the formation and regulation of the state of the innovation environment of the organization. In terms of management methodology, the innovative environment of the organization is a set of conditions of the external (environmental) and internal environment, the composition of which is determined on the whole by the subject area of operation of the management object. The key internal factors include the social and psychological characteristics of the team, the innovative leadership policy, the structure of interpersonal relationships, and so on. In pedagogical research, the educational environment is more often mentioned, emphasizing its role in personality development (Engelbrecht \& Ankiewicz, 2016; Gast, Schildkamp \& van der Veen, 2017).

The study of the innovative environment of HEI as a condition for effective innovative activity of teachers seems to be perspective and requires further attention in our work. The peculiarities of creating an innovative environment are explored in sociocultural works, which focus on the importance of innovative leadership policies. Such policies should, according to researchers, include encouragement (Ridey \& Tolochko, 2017).

To implement measures for managing the innovative activity of higher education institutions, it is necessary to clearly define the list of tasks, the solution of which will contribute not only to the development of innovative activity, but also to profit. It is not possible to achieve such a result without the management of a higher education institution promoting a policy of encouragement (Shorobura, 2010). Therefore, stimulation in HEI can be considered as one of the directions of organizational and managerial support of innovations by the management, which influences the effectiveness of innovative activity of teachers.

When considering the issues of innovation management in the higher education system, researchers focus on the staffing of innovation (Ridey \& Shofolov, 2015). In the scientific literature, the system of advanced training of administrative and managerial staff is defined as a mechanism for introducing organizational innovations in the HEI, thereby emphasizing the importance of management professionalizing activities.

We share this point of view, but we consider the issues of education and scientific and teaching staff as important. In this case, staffing can be seen as a condition for the effectiveness of innovative processes in the HEI (Walder, 2014). A similar point of view is expressed by Gubenko (2017), highlighting as one of the conditions for the development of innovative activity in an educational institution staffing potential, which determines the level of professional competence of the managers and employees of the organization required for innovation.

It is the educational level, the intellectual resource of the institution that reflects the creative ability of the teaching staff to adopt new ideas emerging in the field of education. The quality of professionalism of managers and staff determines the ability of an educational institution to carry out its own research and experimental work or to copy 
new technologies, techniques and other innovations from other organizations. An educational institution that uses the principles of self-study becomes an attractive place of work for highly skilled creative workers, improves relationships with consumers of educational services, partners and increases its competitiveness. In this way, speaking about the involvement of employees in innovation, we emphasize the contribution of all levels of staffing: senior management, management staff and teachers - in each element of the process of involvement.

\section{Material and Methods of Research}

In Investigating the effectiveness of implementing the management of the innovative pedagogical process in higher education institutions (HEI) involved the use of a number of methods of scientific and empirical cognition. The use of the method of analysis of the current state of management and operation of the innovation process in HEI allowed to decompose the material under study into units, to study the separate parts of the elements. In its turn, the use of the synthesis method contributed to combining the individual parts of knowledge into a whole, which was reflected in the technology of organizing the innovative process at the departments of HEI. Whilst, empirical methods were used to design the author's technology, in particular, the observation of teachers' work aimed at the implementation of innovative pedagogical ideas; comparison of the work of different departments of HEI in order to determine an effective strategy for organizing an innovative educational space.

The study took into account that organization of the process of innovation management in HEIs requires:

- Aligning the purpose of innovation management for the functioning of the HEI as a whole;

- Identifying their competitive advantages and disadvantages (for example, qualified research and development staff, weak investment);

- Identifying methods of innovation management (analytical, experimental, forecasting, economic, socio-psychological, administrative, etc.);

- Building an innovation management mechanism.

The innovation mechanism contains the following stages: forecasting innovations (finding the most probable and promising ways to develop HEIs); innovation planning; situation analysis (collection of data on the state of factors of direct and indirect influence of the external environment, as well as on the state of affairs within the educational organization); identification of the need for innovation; determination of criteria for choosing alternatives for innovation (selection of criteria to compare alternatives to innovation and choosing the best one); development of alternatives; establishing the best of them (often the result of the choice is a compromise that includes the quality of several alternatives; development and coordination of management decisions (the specifics of innovation management is that they are developed, usually by qualified specialists, while the managers make decisions and approve the implementation plan); implementation management (begins with the determination of a set of works and resources, executors and deadlines). After that, they develop a program for the implementation of innovation solutions management, which must be implemented by units in accordance with the HEI development goals tree); control and evaluation of results (control over the implementation of management decisions). If necessary, management assistance or assistance of qualified specialists is provided, adjustments are made in case of errors. Thus there will be feedback from the last element of the innovation management mechanism with the previous ones.

\section{Results}

In modern conditions, the teacher needs not only to choose appropriate teaching methods and methods in specific educational situations, but also to create his own. This is possible if the teacher has the necessary abilities, has received appropriate training, has the means and ways of reflection in relation to his activity, has the means of transition from the description of activity to its criticism and normalization, as well as to compare the methods developed by him with the existing ones (Ridey \& Shofolov, 2015).

Reflection, criticism and design of the teacher's activity suggest correlation of the integrity of the activity with the goals, values and ideals, within the requirements of which it is built and refined. Changing the nature of activities based on increasing the level of pedagogical reflection is timely and relevant. There is no information in the scientific literature about the possibilities of managing the innovative process by increasing the level of pedagogical reflection of teachers in the real conditions of work of structural parts of HEI, in particular we are talking about the departments. The solution to this problem is an urgent scientific challenge. Pedagogical reflection is related to the teacher's awareness of conflicts in his or her activity (Orazbayeva, 2016). The disclosure of these contradictions allows us to determine the orientation of the innovative process and the orientation of the pedagogical reflection itself. 
As the research and synthesis of the experience of teachers, methodologists and psychologists demonstrate, innovative practice is most effectively implemented by applying a reflexive approach to managing the creative pedagogical process. Important advantages of a reflexive approach to the organization and management of innovative activities are that this scientific course contributes to the most complete and sufficiently deep involvement of the individual in the co-creation and individual creative process. Therefore, we have proposed a technology for managing the pedagogical process based on the mechanisms of reflection.

Thus, provided that the reflexive approach is implemented, the object of management activity is not the personality or the team, but processes that indirectly affect the teacher. The basic idea is that the object of management is the process of creative activity of teachers. In this approach, the teacher is faced with the choice of responding to a situation that affects personal or social outcomes.

In this context, the pedagogical system is a complex, multifactorial, self-organizing and self-developing system that is capable of "generating" a critically thinking creative personality. The role of this personality in the work of the team is very significant: having a high level of reflection, such a teacher is aware of the need to change professional activity, seeking to create new knowledge through modernization, rationalization or modification.

It is noteworthy that confirmation of this thesis is found in the publications of modern researchers (Arkatov, 2019). In particular, it is said that a creative person who has great innovation potential, as a rule, creates a situation where others have to choose the former stereotype or move to a new activity. Teachers who are self-determined in favour of innovation borrow the perspective of the innovator and adapt it to their activities (Ridey \& Tolochko, 2017).

The structure of indirect management of the innovation process includes the main stages of the reflexive regulation of the search for a new idea: the stages of criticism, conscious rethinking and normalization of the activity. The organizational structure of such management includes the following stages: diagnostic, regulatory, analytical and verification. Knowledge of the varieties of structures and their main stages is necessary to define the whole system of reflective management, because the innovation process consists of micro-innovation processes, which need to be adjusted in communication.

\section{Discussion}

Let us take a closer look at our proposed technology for managing the innovation process in the HEI. Designing innovative activity of the pedagogical system begins with the manager's awareness of the existence of contradictions and the desire to eliminate them is a diagnostic and prognostic stage. For this purpose, the supervisor analyzes the positions of teachers who criticize the state of the system, examines their proposals, builds perspectives for the development of the department regarding the values in education. Management is involved with a teacher-critic who has a high innovative need and creativity. The teacher-critic of the existing system takes the role of the innovator-researcher and connects to the research of problems identified by the leader.

On the basis of the results of the conducted researches, the leader and the innovator formulate new requirements, which are advanced to the level of students' preparation and to the level of teacher's qualification (Figure 1), after which they formulate the goals of the innovative process. Understanding of the restructuring of the pedagogical system is at the level of awareness of the result of the participants' activity of in the educational innovative process by customers: the individual, society, state. 


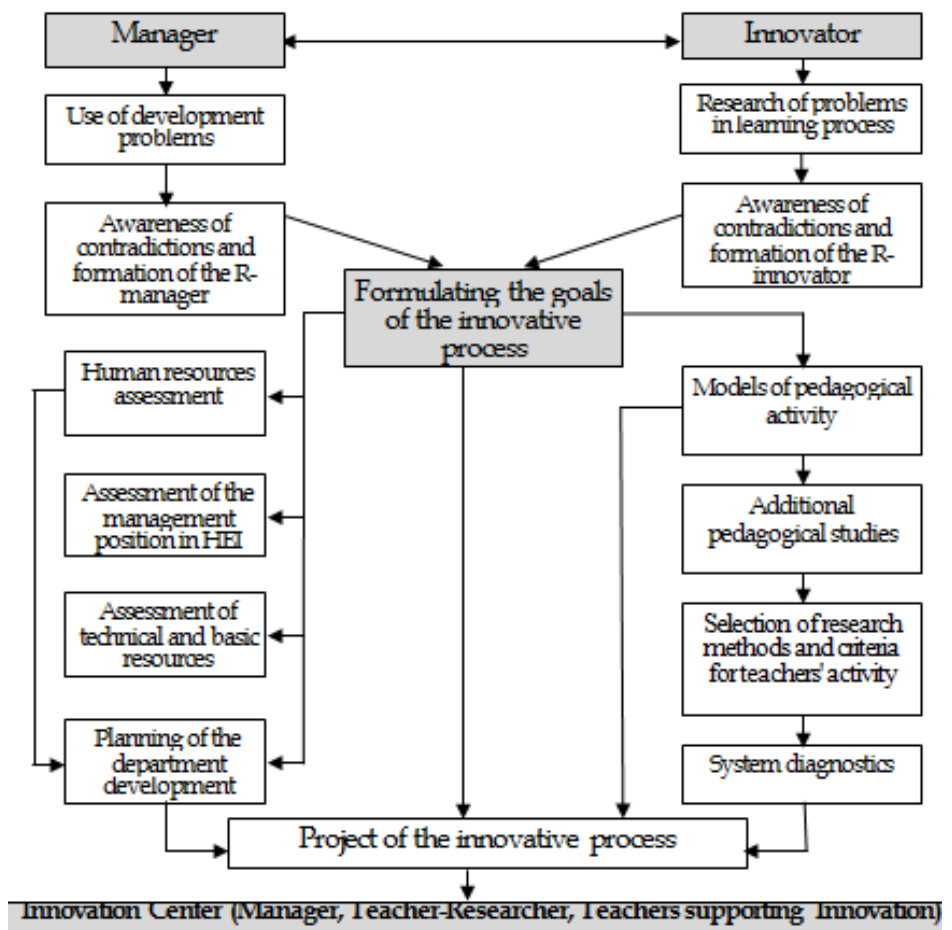

Figure 1. Activities of the head of the department and the teacher-innovator in modelling the innovation process.

Symbols: T-Manager - requirements for the development of an innovative process by a manager; T-innovator requirements for functioning of innovative process from the point of view of teacher-innovator

Generalized structure of existing activity and its prospective model allows to develop a model for managing innovative educational process. The model-image of pedagogical activity consists of a limited period of time and is a "private" model that takes into account the peculiarities of the development of a particular department.

The main reason for the short-term nature of this model is the accelerated pace of scientific and technological progress and the informatization of education, which entails the development of information processing tools. All these conditions are capable of making significant changes in the activity of the department.

Consider the activity of preparing an innovative process at the department. The manager evaluates external conditions and internal resources for successful introduction of innovations, develops the project and technology of realization of activity in real working conditions of the department staff regarding the following:

1) The teacher is considered as an active participant in the innovative process, who develops their abilities (first of all - the ability to reflect);

2) Pedagogical reflection is a process that can be initiated and directed, and is the basis for managing teacher's activity;

3) The initiation of reflexive orientation occurs with awareness of difficulties in the process of pedagogical activity to remove these difficulties;

4) Requirements for the level of professional competence of the teacher are formed in accordance with the needs of the individual (student), society, state, current trends in the development of education.

The implementation of this technology is carried out by means of creative type of communication (Figure 2), which is aimed at:

- $\quad$ Loosening stereotypes in the activity of the teacher through the awareness of existing contradictions;

- $\quad$ Identifying the causes of contradictions and their dependence on their own activity by the teacher;

- Finding solutions to these contradictions;

- Constructing new activities to solve them. 


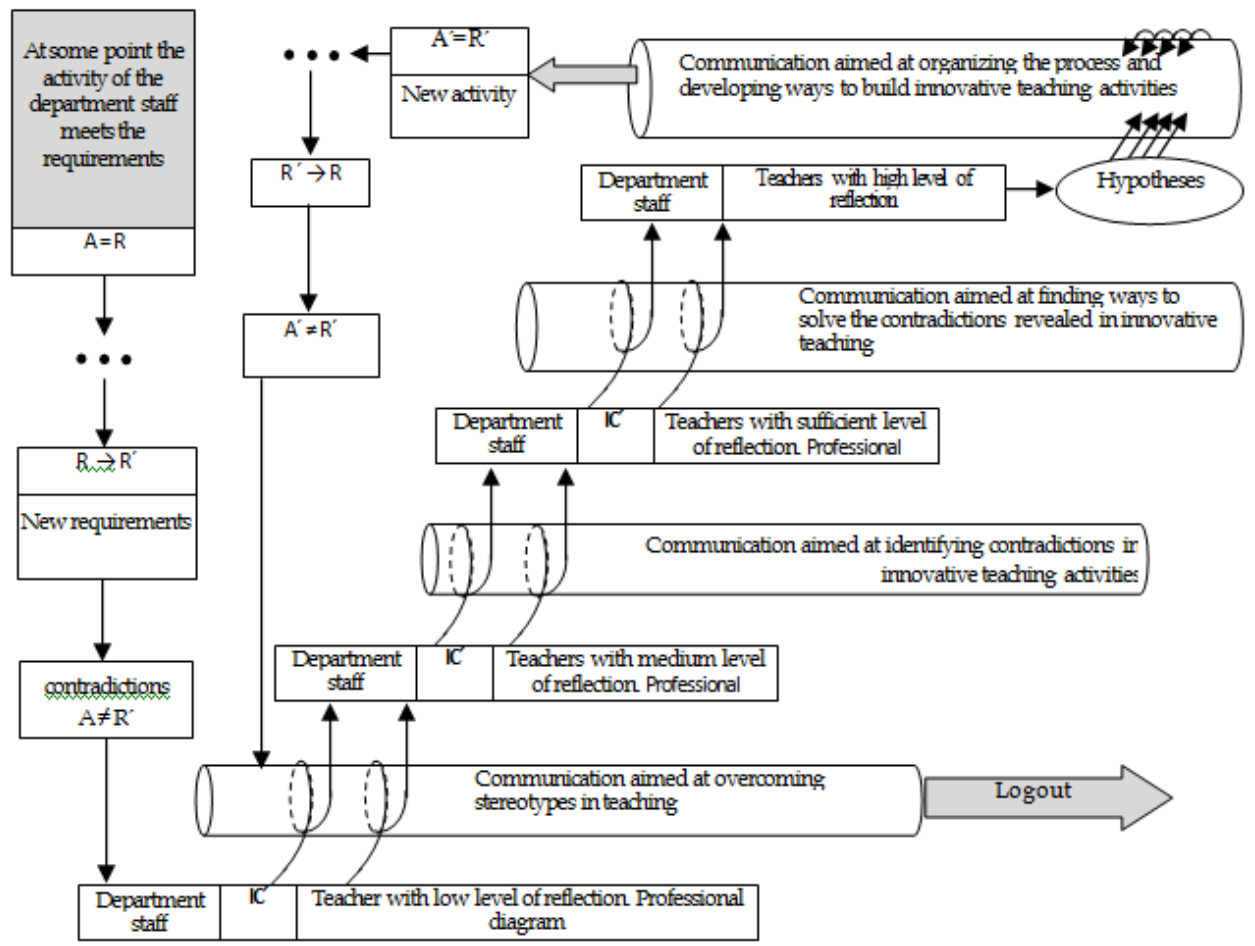

Figure 2. The scheme of organizing innovative process. Symbols: A - activity; R - requirements; R' - new requirements; A' - new activity; IC - innovation centre

Communication can be dialogical, group centred, collective, carried out in the form of discussions, seminars and meetings of the department. The main requirements for communication are their orientation and high level of teachers' willingness to participate in communications. Communication is seen as a semantic aspect of social interaction and motivation.

The main functions of communication interaction are to achieve a collective community while maintaining the individuality of each participant. In communication, there occurs the transition to a fundamentally new form of relationships. Due to the inconsistency of understanding of pedagogical activity, existing problems in communication, there is a need to avoid extreme forms of "mutual resistance", to take into account the attitude of others, to change the activity of everyone so that it is acceptable for all members of the team.

Communication of the first level is informative. Its main task is to promote the teacher's feeling of dissatisfaction with the work of the team, its inconsistency with the modern requirements, that is, the awareness of contradictions between existing activities and the requirements imposed on it. The second stage of communication is aimed at identifying the causes of contradictions. As a result, teachers are aware that it is possible to resolve the contradictions by changing their own activity.

The organization of communication of the third and fourth levels is carried out according to the same scheme. The content of communications in the third stage is the analysis of colleagues' activities and introspection. The result is a high level of reflection, teachers are able not only to identify the contradictions and their causes, but also to find ways to resolve these marked contradictions, to create an image of a new activity. Communication of the fourth stage is characterized by the fact that there is a search for ways to carry out activities that meet the new standards.

To ensure continuous innovative activity of the teacher on the basis of increasing the level of pedagogical reflection, it is necessary to have internal conditions (at the department level) and external (at the university level). Internal conditions:

- Head of the department with reflexive management methods and high innovative need;

- Researcher, able to identify contradictions and develop a new standard of activity that allows to remove them; 
- Conditions for exchanging views and experience on the basis of openness and accessibility of the results of the activity;

- A system of encouragement and social protection.

Basic requirements for external conditions:

- Clear distinction of managerial functions among the administration of the HEI, the faculty and the department;

- System of promotion and social protection;

- Availability of a document that guarantees copyright and non-interference in the creative process;

- Guaranteeing certain material resources needed to support innovation;

- Humanistic orientation of university development;

- Focusing the attention of university management on the educational process. After the introduction of innovation in the pedagogical process, the stage of slowing down transformations inevitably comes, stability emerges. Followers of the new approach persist in realizing and developing innovation.

\section{Conclusions}

Considering the process of innovation management in educational institutions, we can define the innovation activity in HEI as a set of processes: educational, scientific-innovative and strategic processes of human potential formation. Teachers in the higher education organization may be involved in these processes. Considering the innovative activity of teachers, it is advisable to emphasize the motivation and willingness to innovate. It should be taken into account that the effectiveness of innovative activity is ensured if the teachers are motivated, they have the readiness to innovate, capable of removing the causes of resistance, that is, the teachers are involved in innovation. This is ensured by the implementation of the author's technology for managing the innovation process at the department. Extrapolation of the structural parts of the developed technology to the organization of the work of HEI will ensure effective management of innovation processes in the specified educational organization.

\section{Prospects for Further Scientific Investigation}

Further research may be related to the development of the theory of teacher's involvement into innovation at other levels of education and management; issues of inter-university interaction in the implementation of innovations and the educational process of the HEI and involvement of teachers in this activity; questions of studying the features of management in the innovative educational process depending on specificity of HEI; with the development of a system for monitoring the level of involvement of teachers in the innovative activities of the HEI.

\section{References}

Arkatov, Y. N. (2019). Analysis and mathematical modelling of the elements of the educational process. In Materials of All-Ukrainian Research Conference: Quality Management Training, 7-9. Odessa, Ukraine.

Aškerc, K., \& Kočar, S. (2015). Teaching and the Pedagogical Training of University Teaching Staff-Practice and Opinions under Slovenian Higher Education Legislation. Education Inquiry, 6(2), 25591. https://doi.org/10.3402/edui.v6.25591

Bendahmane, M., El Falaki, B., \& Benattou, M. (2019). Toward a personalized learning path through a services-oriented approach. International Journal of Emerging Technologies in Learning, 14(15), 52-66. http://doi.org/10.3991/ijet.v14i15.10951

Bondar, D. V. (2013). Theoretical Foundations of Innovative Mechanisms of Public Administration in Management Training in Higher Education: monograph. Kharkiv, Ukraine: Oberig.

Bovill, C., Cook-Sather, A., Felten, P., Millard, L., \& Moore-Cherry, N. (2016). Addressing potential challenges in co-creating learning and teaching: overcoming resistance, navigating institutional norms and ensuring inclusivity in student - staff partnerships. Higher Education, 71(2), 195-208. https://doi.org/10.1007/s10734-015-9896-4

DCU. (2018). Overview - Research Network. Retrieved from https://www.dcu.ie/nidl/research/overview.shtml 
Dysart, S. A., \& Weckerle, C. (2015). Professional development in higher education: A model for meaningful technology integration. Journal of Information Technology Education: Innovations in Practice, 14, 255-265. https://doi.org/10.28945/2326

Engelbrecht, W., \& Ankiewicz, P. (2016). Criteria for continuing professional development of technology teachers' professional knowledge: A theoretical perspective. International Journal of Technology and Design Education, 26(2), 259-284. https://doi.org/10.1007/s10798-015-9309-0

Gamayunov, V. G. (2003). Formation of didactic management in the system of state management of education $(\mathrm{PhD}$ dissertation). Donetsk State Academy of Management of the Ministry of Education and Science of Ukraine, Donetsk, Ukraine.

Gast, I., Schildkamp, K., \& van der Veen, J. T. (2017). Team-Based Professional Development Interventions in Higher Education: A Systematic Review. Review of educational research, 87(4), 736-767. https://doi.org/10.3102/0034654317704306

Gubenko, A. (2017). Mechanisms for implementation of educational and educational technologies in higher education. Power and society (history, theory, practice), 1(41), 64-73.

Kneale, P., Winter, J., Turner, R., Spowart, L., Hughes, J., McKenna, C., \& Muneer, R. (2016). Evaluating Teaching Development in Higher Education. Towards Impact Assessment: Literature Review. York, UK: Higher Education Academy.

Koehler, M. J., Mishra, P., Kereluik, K., Shin, T. S., \& Graham, C. R. (2014). The technological pedagogical content knowledge framework. In M. Spector, M. D. Merrill, J. Ellen \& M. J. Bishop (Eds.), Handbook of Research on Educational Communications and Technology: Fourth Edition, 101-111. New York, NY: Springer. https://doi.org/10.1007/978-1-4614-3185-5_9

Orazbayeva, K. (2016). Professional Competence of Teachers in the Age of Globalization. International Journal of Environmental \& Science Education, 11(9), 2659-2672. http://dx.doi.org/10.12973/ijese.2016.714a

Prokopenko, A. I. (2013). Management in the modern education system. Kharkiv, Ukraine: G. S. Skovoroda KhNPU.

Ravhuhali, F., Kutame, A. P., \& Mutshaeni, H. N. (2015). Teachers' perceptions of the impact of continuing professional development on promoting quality teaching and learning. International Journal of Educational Sciences, 10(1), 1-7. https://doi.org/10.1080/09751122.2015.11890332

Ridey, N. M. (2010). Pedagogical innovation: education for steady development. Trends in education, 3(1), 236-240.

Ridey, N. M., \& Shofolov, D. L. (2015). Analysis of the scientific well-being of teachers in the formation of professional competence in management. In Proceedings of the 5th International Scientific and Practical Conference: Modern Postgraduate Education: Traditions and Innovations, 40-42. Kyiv, Ukraine.

Ridey, N. M., \& Tolochko, S. (2017). Methodology of expert assessment of the results ofcognition, programs and development plans. In A. Bereza, T. Parczewska, \& B. Bednarczuk (Eds.), Development and modernization of pedagogical and psychological sciences: experience of Poland and prospects of Ukraine, 3, 170-189. Lublin, Poland: Izdevnieciba "Baltija Publishing".

Sadkovy, V. P., \& Dombrovska, S. M. (2012). The Bologna process as one of the directions of state education reform. Retrieved from https://nuczu.edu.ua/sciencearchive/PublicAdministration/vol1/44-48.pdf

Shorobura, I. M. (2010). Pedagogical management: a lecture course. Kamianets-Podilskyi, Ukraine: Zvoleyko D. G.

Starostina, A., Kravchenko, V., \& Nazvanova, L. (2013). Usage of the intellectual property of the university scientists within the concept of open innovation: opportunities and risks for Ukraine. Bulletin of Taras Shevchenko National University of Kyiv. Economics, 144, 47-51. https://doi.org/10.17721/1728-2667.2013/144-3/15

Stefani, L. (2013). Performance measurement for academic development: risk or opportunity? International Journal for Academic Development, 18(3), 294-296. https://doi.org/10.1080/1360144X.2013.818542

Stes, A., De Maeyer, S., Gijbels, D., \& Van Petegem, P. (2013). Effects of teachers' instructional development on students' study approaches in higher education. Studies in Higher Education, 38(1), 2-19. https://doi.org/10.1080/03075079.2011.562976 
Stewart, C. (2014). Transforming professional development to professional learning. Journal of Adult Education, 43(1), 28-33.

Suprun, A., \& Novytska, K. (2015). Innovations and creativity as a basis for of changes the educational paradigm. Scientific Journal of NULES of Ukraine. Series: Liberal Arts, 228, 97-102.

Sidorenko, V. V. (2016). Innovative directions of scientific and methodological support professional development of teaching staff at post-graduate education. Information collection for the headmaster and kindergarten teacher, 7-8(48), 22-29.

Tolochko, S. (2016). Economic competitiveness and modern pedagogics definitions correlation. Baltic Journal of Economic Studies, 2(1), 101-107. https://doi.org/10.30525/2256-0742/2016-2-1-101-106

Walder, A. M. (2014). The concept of pedagogical innovation in higher education. Education Journal, 3(3), 195-202. https://doi.org/10.11648/j.edu.20140303.22

Watty, K., McKay, J., \& Ngo, L. (2016). Innovators or inhibitors? Accounting faculty resistance to new educational technologies in higher education. Journal of Accounting Education, 36, 1-15. https://doi.org/10.1016/j.jaccedu.2016.03.003

Webster, L., \& Whitworth, A. (2019). Power and Resistance in Informed Learning. In K. Ranger (Ed.), Informed Learning Applications: Insights from Research and Practice, 115-131. Bingley, UK: Emerald Publishing Limited. https://doi.org/10.1108/S0065-283020190000046010 